\title{
OPTIMUM FIELD ELEMENT SIZE FOR MAXIMUM YIELDS IN WINTER WHEAT USING \\ VARIABLE NITROGEN RATES
}

\author{
By \\ JOANNE MARIE LA RUFFA \\ Bachelor of Science \\ Virginia Polytechnic Institute and State University \\ Blacksburg, Virginia \\ 1996
}

Submitted to the Faculty of the

Graduate College of the

Oklahoma State University

in partial fulfillment of

the requirements for

the Degree of

MASTER OF SCIENCE

May, 1999 
OKLAHOMA STATE UNIVERSTTY

\author{
OPTIMUM FIELD ELEMENT SIZE FOR MAXIMUM \\ YIELDS IN WINTER WHEAT USING \\ VARIABLE NITROGEN RATES
}

Thesis Approved:

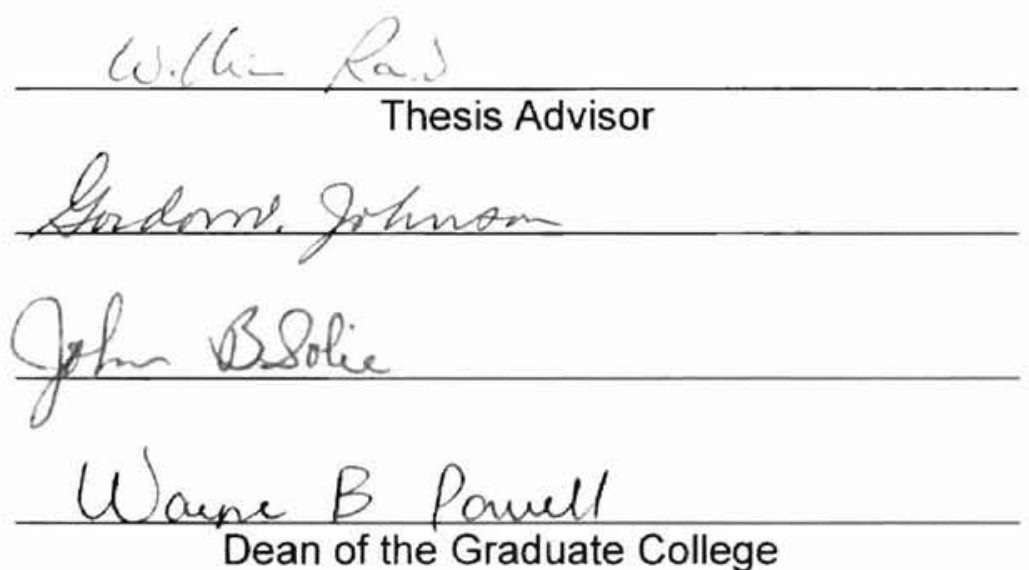




\section{ACKNOWLEDGMENTS}

I wish to express my gratitude to Oklahoma State University and the Department of Plant and Soil Sciences for allowing me the opportunity to pursue this degree. I would like to extend my sincere appreciation to my advisor, Dr. William Raun, for his wisdom, guidance, and friendship. I would also like to acknowledge my other committee members, Dr. Gordon Johnson and Dr. John Solie. Finally, I would like to express my heartfelt appreciation to all the individuals involved in the Soil Fertility Project. 
TABLE OF CONTENTS

Chapter

Page

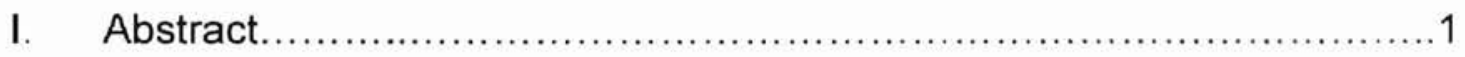

II. Literature Review................................................... 1

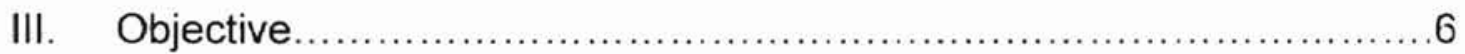

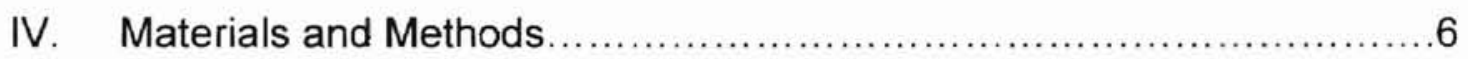

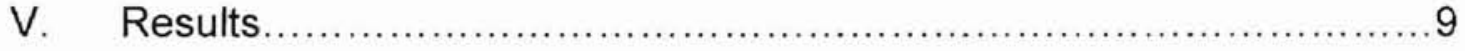

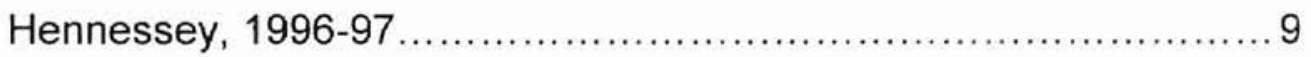

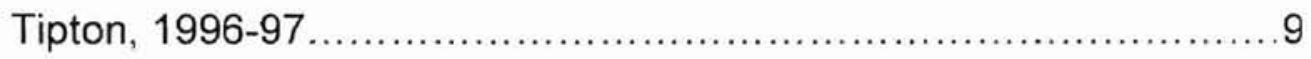

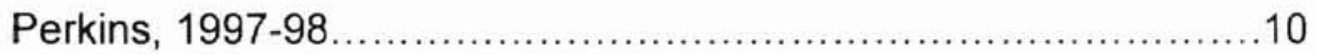

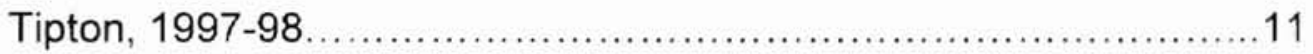

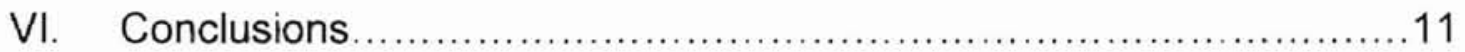

VII. References ............................................................... 13

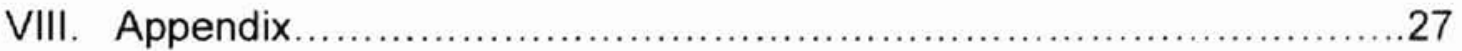




\section{LIST OF TABLES}

Table

Page

1. Initial surface $(0-15 \mathrm{~cm})$ soil test characteristics and soil classification at Hennessey, Perkins, and Tipton, Oklahoma.

2. Treatment structure for resolution study.

3. Linear regression models determined for a linear NDVI $-\mathrm{N}$ rate scale.

4. Analysis of variance for NDVI, nitrogen rate, grain yield, nitrogen uptake, and efficiency of use in wheat at Hennessey, OK, 1996-97.

5. Analysis of variance for NDVI, nitrogen rate, grain yield, nitrogen uptake, and efficiency of use in wheat at Tipton, OK, 1996-97.

6. Analysis of variance for NDVI, nitrogen rate, grain yield, nitrogen uptake, and efficiency of use in wheat at Perkins, OK, 1997-98.

7. Coefficients of variation, by treatment, for grain yield and efficiency of use in wheat at Perkins, OK, 1997-98.

8. Analysis of variance for NDVI, nitrogen rate, grain yield, nitrogen uptake, and efficiency of use in wheat at Tipton, OK, 1997-98.

9. Coefficients of variation, by treatment, for grain yield and efficiency of use in wheat at Tipton, OK, 1997-98. 


\section{LIST OF FIGURES}

Figure

Page

1. Diagram of the physical layout of the experiments showing treatments (1-4) and resolution within treatment. 


\title{
OPTIMUM FIELD ELEMENT SIZE FOR MAXIMUM YIELDS IN WINTER WHEAT USING VARIABLE NITROGEN RATES
}

\begin{abstract}
The resolution at which variability in soil test and yield parameters exists is fundamental to the efficient use of real-time sensor-based variable rate technology (s-VRT). This study was conducted to determine the optimum field element size that would account for the spatial variability of nitrogen in winter wheat (Triticum aestivum L.). The effect of nitrogen variability on yield was investigated at Tipton, Hennessey, and Perkins, Oklahoma. Results indicate that variability exists at resolutions less than or equal to one square meter. Increased yields at smaller harvested resolutions and reduced fertilizer costs are expected when using variable nitrogen rates based on NDVI values. Results from this study suggest that application of prescribed fertilizer rates based on differences at the $0.84 \mathrm{~m}^{2}$ resolution could lead to increased yields, decreased grower costs, and decreased environmental impact of excess fertilizers.
\end{abstract}

\section{LITERATURE REVIEW}

Soil testing is the most widely used method to detect nutrient availability. However, a composite sample estimates the mean soil test nutrient level which does not address the variability encountered in that field (Raun et al., 1998). 
Wibawa et al. (1993) evaluated the influence of soil fertility variation using grid sampling to generate detailed soil maps of each field. Results indicated that variation of soil $\mathrm{NO}_{3}-\mathrm{N}$ occurred over very short distances within a $15 \mathrm{~m}^{2}$ grid. Wibawa et al. (1993) also observed yield increases as a result of variable rate fertilization based on $15 \mathrm{~m}^{2}$ grid sampling versus a $76 \mathrm{~m}^{2}$ grid. These results indicated that a smaller grid area provided a more accurate estimate of soil nutrient availability.

Penney et al. (1996) also evaluated nutrient variability using grid sampling Results, using a $67 \mathrm{~m}^{2}$ grid, revealed very large differences in $\mathrm{NO}_{3}-\mathrm{N}$ levels within the field. This indicated that a constant rate of $\mathrm{N}$ applied based on a composite sample of the field would result in over fertilization of the areas with high levels of $\mathrm{N}$ and under fertilization of large areas with low levels of available N. Penney et al. (1996) also refers to the fact that the cost of intensive grid sampling is high and alternative methods are needed for mapping the spatial variability of soil nutrients. According to Han et al. (1994), if a field is subdivided into small enough regions (grid cells), the soil properties within the regions will be uniform, hence, application rates and actual soil productivity are closely matched. A minimum cell size of $20 \mathrm{~m}^{2}$ would be responsive to the $\mathrm{NO}_{3}-\mathrm{N}$ distribution based on the spatial variability of crop production factors in the field. Cahn et al. (1994) characterized spatial patterns of soil properties and nutrient concentrations for site-specific farming. They concluded that reducing sampling intervals from $50 \mathrm{~m}$ to $1 \mathrm{~m}$, would reduce the variance of soil water content (SWC), soil organic carbon (SOC), $\mathrm{NO}_{3}-\mathrm{N}, \mathrm{PO}_{4}-\mathrm{P}$, and $\mathrm{K}$ estimates by $74,95,25$. 
64 , and $58 \%$, respectively. They also indicated that $\mathrm{NO}_{3}-\mathrm{N}$ had the shortest correlation range $(<5 \mathrm{~m})$, which refers to the distance between samples.

Chancellor and Goronea (1994) stated that there may be considerable potential benefit from sampling at $<1 \mathrm{~m}$ intervals, as their results indicated a $12 \%$ increase in $\mathrm{N}$ use efficiency when application of $\mathrm{N}$ was based on sampling intervals $<1 \mathrm{~m}$ versus intervals $>1 \mathrm{~m}$. Through the application of yield mapping to corn silage production, Vansichen and de Baerdemaeker (1993) concluded that $67 \%$ of the variability in yield could be explained by the sampled soil variables. In a similar study, Mulla et al. (1992) studied variable rate fertilizer applications for the Palouse region of eastern Washington, which has complex soil fertility and crop productivity patterns due to steep, highly erodible hills, resulting in drastic soil variability. Results from this study indicated that improvements in $\mathrm{N}$ fertilizer response were achieved by applying variable rates of fertilizer depending on landscape position.

Sensor based variable rate technology (s-VRT) has the ability to detect submeter-variability of nutrients on-the-go and simultaneously apply prescribed fertilizer rates based on those needs, thus realizing the potential to increase yields, decrease grower costs, and decrease the environmental impact of excess fertilizers. In order to effectively utilize s-VRT, Sawyer (1994) suggested that within-field variation must be accurately identified and reliably interpreted. Therefore, there is a need to establish the optimum field element size, which is fundamental to s-VRT in order to detect micro-variability of nutrients, such as nitrogen. Solie et al. (1996) define the optimum field element size as that area 
which provides the most precise measure of the available nutrient where the level of that nutrient changes with distance. They proposed 0.8 to $1.4 \mathrm{~m}$ as the range for the field element size. The field element size should identify the smallest resolution where cause and effect relationships can be measured, where misapplication could pose a risk to the environment, where net economic return can be achieved, and where differences in yield potential may exist (Raun et al., 1998). Sensing and applying fertilizer based on the optimum field element size should provide the most precise measurement of actual crop need and its application to the crop (Solie et al., 1996).

Sawyer (1994) recently pointed out that on-the-go sensing was still futuristic; however, new developments by Stone et al. (1996) have demonstrated that sensor based systems are capable of detecting nutrient variability, and research is being conducted to more fully develop s-VRT. The initial sensor based system at Oklahoma State University measured spectral irradiance or light energy per unit area. Irradiance is sensitive to sunlight, illumination angle, crop direction, and cloud cover. The current sensor based system measures reflectance. Spectral irradiance measurements are obtained using an integrated sensor with photodiode-based sensors and interference filters for red $(671 \pm 6$ $\mathrm{nm}$ ) and near infrared (NIR, $780 \pm 6 \mathrm{~nm}$ ) (Stone et al., 1996b). Up-oriented and down-oriented sensors measure solar spectral irradiance and plant surface irradiance, respectively. Reflectance values are calculated as a ratio of the incident and reflected radiation. Measurements taken at these wavelengths can be used to calculate a normalized-difference-vegetative-index (NDVI), which has 
been demonstrated to be highly correlated with plant $\mathrm{N}$ uptake (Stone et al., 1996a), and a reliable predictor of topdress $\mathrm{N}$ needs (Roth et al., 1989).

Numerous studies have indicated that reflectance at specific wavelengths can aid in the detection of soil variables, such as soil $\mathrm{N}$ content. Dalal and Henry (1986) characterize the NIR spectral region as being dominated by combinations of vibrational bands of light atoms that have strong molecular bonds. They site examples such as chemical bonds that contain $\mathrm{H}$ attached to atoms such as $\mathrm{N}$, $\mathrm{O}$, or $\mathrm{C}$. They suggest that through near infrared diffuse reflectance spectrophotometry, it may be possible to measure moisture, organic $\mathrm{C}$, and $\mathrm{N}$ in the soil. Marten et al. (1985) indicate that light-absorption characteristics due to $\mathrm{H}$ bonding of the organic components of forage cause the reflectance which enables scientists to identify plant composition. Morra et al. (1991) also indicate that each component of an organic mixture has unique absorption properties in the NIR spectral region $(700-2500 \mathrm{~nm})$ due to the stretching and bending vibrations of bonds between elements.

Thomas and Gausman (1977) concluded that reflectance in the visible spectral region is primarily influenced by chlorophyll and carotenoid. Further, Thomas and Oerther (1972) concluded that leaf reflectance, as a function of chlorophyll content, at 550 and $675 \mathrm{~nm}$ can be used to predict $\mathrm{N}$ status in sweet peppers. Wood et al. (1992) researched the prospect of using field chlorophyll measurements for the evaluation of $\mathrm{N}$ status in corn. They suggested that since leaf chlorophyll is directly related to leaf $\mathrm{N}$ concentration, it may aid in predicting the $\mathrm{N}$ requirement for crops. Results from Blackmer et al. (1994) also indicate 
that chlorophyll content can be correlated with leaf $\mathrm{N}$ concentration and emphasize that reflectance at $550 \mathrm{~nm}$ is useful in detecting $\mathrm{N}$ deficiencies in corn leaves. Walburg et al. (1982) researched the effects of $\mathrm{N}$ on reflectance patterns in corn and found that red reflectance increased and near infrared reflectance decreased in low $\mathrm{N}$ canopies. Similarly, Hinzman et al. (1986) found that visible reflectance decreased and near infrared reflectance increased with $\mathrm{N}$ fertilization in winter wheat. Kleman and Fagerlund (1987) studied the spectral radiance of barley and analyzed the results as related to biomass, water content, and grain yield. They found that the ratio of IR to red was strongly correlated to the amount of biomass in barley. Roth et al. (1989) concluded that the whole-plant total $\mathrm{N}$ between Feekes growth stages 3 and 6 (Large, 1954) can be used as the basis for $\mathrm{N}$ fertilizer recommendations in winter wheat.

\section{OBJECTIVE}

The objective of this study was to determine the optimum field element size for maximum yields in winter wheat using variable nitrogen rates based on sensor readings and the calculated NDVI values.

\section{MATERIALS AND METHODS}

Two studies were initiated in January 1997 at Tipton and Hennessey, Oklahoma. The study was continued in 1998 at Tipton and Perkins, Oklahoma. 
Soil types and initial soil test results are reported in Table 1. All the sites were $\mathrm{N}$ deficient, had no $\mathrm{P}$ or $\mathrm{K}$ deficiencies, and had adequate $\mathrm{pH}$. Winter wheat (Triticum aestivum L.) 'Tonkawa' had been previously established at all sites at a seeding rate of $78 \mathrm{~kg} \mathrm{ha}^{-1}$. The wheat was planted at Tipton on October 7, 1996 and on October 2, 1996 at Hennessey using $0.19 \mathrm{~m}$ row spacing. For the second year of the study, wheat was planted at Tipton on October 16, 1997 and on October 21, 1997 at Perkins using $0.19 \mathrm{~m}$ row spacing. At each location, a completely randomized design was employed. Four treatments, varying in treated resolution, were replicated three times at both sites onto $53.51 \mathrm{~m}^{2}$ plots. The four treatments are defined in Table 2 and illustrated in Figure 1.

At Feekes growth stage 5 an optical sensor developed at Oklahoma State University measured red $(671 \pm 6 \mathrm{~nm})$ and near-infrared $(\mathrm{NIR}, 780 \pm 6 \mathrm{~nm})$ wavelengths in each subplot. The sensor was mounted on the front of a John Deere model 318 lawn and garden tractor with a field of view of $0.91 \mathrm{~m}$. Approximately 10 readings were taken per $0.84 \mathrm{~m}^{2}$. In 1996-97, a normalizeddifference-vegetative-index (NDVI) was calculated from the sensor measurements obtained for red and NIR uncalibrated voltage readings, according to the following equation:

$$
\text { NDVI }=\frac{\text { NIR-red }}{\text { NIR+red }}
$$

In 1997-98, NDVI was calculated from calibrated voltage readings, which accounted for incoming light. NDVI was calculated according to the following equation: 


$$
N D V I=\frac{\frac{N I R_{\text {down }}}{N I R_{\text {up }}}-\frac{\text { Red }_{\text {down }}}{\operatorname{Red}_{\text {up }}}}{\frac{N I R_{\text {down }}}{N I R_{\text {up }}}+\frac{\operatorname{Red}_{\text {down }}}{\operatorname{Red}_{\text {up }}}}
$$

In 1996-97, variable $\mathrm{N}$ rates were determined for the subplots based on a linear NDVI - $\mathrm{N}$ rate scale. Subplots with the lowest NDVI values received the highest fertilizer $\mathrm{N}$ rate $\left(112 \mathrm{~kg} \mathrm{ha}^{-1}\right)$ and the highest NDVI values received the lowest fertilizer $\mathrm{N}$ rate $\left(0 \mathrm{~kg} \mathrm{ha}^{-1}\right)$. Linear regression models were determined in Excel (Table 3). An identical linear NDVI - N rate scale was utilized at Perkins in 199798. However, a ramped NDVI $-\mathrm{N}$ rate scale was utilized at Tipton in 1997-98 to account for variation in percent coverage or stand density. The linear NDVI - N rate scale was based on previous experience reported by Stone et al. (1996a). From these scales, the amount of $\mathrm{N}$ fertilizer for each subplot was determined and the appropriate amount of ammonium nitrate was broadcast applied by hand.

Each location was harvested with a Massey Ferguson 8XP self-propelled combine in late May or early June. The entire subplot area was harvested and grain weights and percent moisture were automatically recorded. Pre-harvest calibration of the combine scales indicated that weights had precision error of \pm $15.44 \mathrm{~g}$. Grain samples were collected and weighed on lab scales when yields were low $(<15.44 \mathrm{~g})$. Grain was ground to pass a 140 mesh screen and total nitrogen content in grain was analyzed using a Carlo Erba NA 1500 dry combustion analyzer (Schepers et al., 1989). The efficiency of use index was calculated as grain yield/N rate (Moll et al., 1982). Nitrogen uptake was 
determined by multiplying percent $\mathrm{N}$ in the grain by grain yield. Statistical analysis was performed using SAS (SAS Institute, 1988).

\section{RESULTS}

Response to treatment resolution and applied $\mathrm{N}$ fertilizer was variable in the two years of this experiment. The following details the results by location and year.

\section{Hennessey, 1996-97}

There was no significant influence of resolution on $\mathrm{N}$ rate, yield, $\mathrm{N}$ uptake, or efficiency of use (Table 4). The NDVI values for this location ranged from 0.70 to 0.81 (mean of $0.78 \pm 0.01$ ) and were normally distributed. However, 90 percent of the plots had NDVI values greater than 0.75 . Also, the CV (coefficient of variation) for NDVI was very low (1), thus indicating that only very limited variability existed at this site. Also, a large portion of the experiment had high NDVI values (high N uptake) and was likely non-responsive. Because of this, low $\mathrm{N}$ rates were applied to areas where no response was expected and high $\mathrm{N}$ rates were applied where only limited increases were realistic.

\section{Tipton, 1996-97}

NDVI values at this location ranged from 0.18 to 0.48 (mean of $0.34 \pm$ 0.05 ) and were normally distributed. More variability in NDVI was found at this 
site than the Hennessey site. Grain yields were drastically lower at Tipton compared to Hennessey due to freeze damage on April 11, 12 and 13. There was no significant influence of resolution on $\mathrm{N}$ rate, yield, $\mathrm{N}$ uptake or efficiency of use (Table 5). However, it should be noted that environmental factors strongly influenced results at this site.

Perkins, $1997-98$

NDVI values at this location ranged from 0.28 to 0.63 (mean of $0.42 \pm$ $0.05)$ and were normally distributed. The linear NDVI $-\mathrm{N}$ rate scale used was expected to encompass the entire range of $\mathrm{N}$ needs (maximum $\mathrm{N}$ need at NDVI $=0.28$ and limited $\mathrm{N}$ need at NDVI $=0.63$ ). There was no significant influence of resolution on $\mathrm{N}$ rate, yield, $\mathrm{N}$ uptake or efficiency of use (Table 6). However, there was a trend for a lower $\mathrm{N}$ rate and a higher efficiency of use for the $0.84 \mathrm{~m}^{2}$ resolution. Although nitrogen uptake was somewhat lower for the highest resolution $\left(0.84 \mathrm{~m}^{2}\right)$, it was important to find that the standard deviation was lower at this resolution when compared to coarser treatments (means of $51.53 \pm$ $1.88,52.30 \pm 5.81,54.21 \pm 4.67$, and $60.27 \pm 6.63$ for the $0.84,3.34,13.38$, $53.51 \mathrm{~m}^{2}$ resolutions, respectively). This suggests that treating the nitrogen uptake variability at early stages of growth could result in increased yield and nitrogen uptake homogeneity. Finally, it is important to recognize that the CVs separated by treatment for yield and efficiency of use were lowest for the $0.84 \mathrm{~m}^{2}$ resolution (Table 7), thus suggesting that small-scale management assisted in decreasing treatment heterogeneity. 


\section{Tipton, 1997-98}

NDVI values at this location ranged from 0.28 to 0.79 (mean of $0.56 \pm$ 0.08 ) with a bimodal distribution. Grain yields increased for the coarser resolutions at this site (Table 8). There was no significant influence of resolution on $\mathrm{N}$ rate, efficiency of use or $\mathrm{N}$ uptake. However, there was a trend for a higher efficiency of use at the $0.84 \mathrm{~m}^{2}$ resolution. Also, a significant quadratic relationship was found between efficiency of use and resolution. Finally, it is important to recognize that the CVs separated by treatment for yield and efficiency of use were lowest for the $13.38 \mathrm{~m}^{2}$ resolution (Table 9), thus suggesting that the micro-variability was better managed.

\section{CONCLUSIONS}

Although results only slightly varied by location and year, a few lessons have been learned from the resolution study. First, at Hennessey, 1996-97, a large portion of the experiment had high NDVI (high N uptake) and was likely non-responsive. Because of this, low $\mathrm{N}$ rates were applied to areas where no response was expected and high $\mathrm{N}$ rates were applied where only limited increases were realistic. Next, the importance of stand density was recognized at Tipton, 1997-98. This was taken into account in the NDVI $-\mathrm{N}$ rate calibration. Finally, the VRT research group has employed a sensor that accounts for incoming light, thus resulting in calibrated NDVI. This study is being continued 
during the 1998-99 season where concepts such as cutoff points for responsive and non-responsive regions of the NDVI - $\mathrm{N}$ rate relationship are being refined in terms of stand density, stage of growth, and yield potential. Further, when NDVI is low, a method of determining whether the value is a function of poor coverage or of other factors, such as low $\mathrm{N}$ uptake, is necessary. 


\section{REFERENCES}

Blackmer, T.M., J.S. Schepers, and G.E. Varvel. 1994. Light reflectance compared with other nitrogen stress measurements in corn leaves. Agron. J. 86:934-938.

Cahn, M.D., J.W. Hummel, and B.H. Brouer. 1994. Spatial analysis of soil fertility for site-specific crop management. Soil Sci. Soc. Am. J. 58:12401248.

Chancellor, W.J. and M.A. Goronea. 1994. Effects of spatial variability of nitrogen, moisture, and weeds on the advantages of site-specific applications for wheat. Trans. ASAE 37(3):717-724.

Dalal, R.C. and R.J. Henry. 1986. Simultaneous determination of moisture, organic carbon, and total nitrogen by near infrared reflectance spectrophotometry. Soil Sci. Soc. Am. J. 50:120-123.

Han, S., J.W. Hummel, C.E. Goering, and M.D. Cahn. 1994. Cell size selection for site-specific crop management. Trans. ASAE 37(1):19-26.

Hinzman, L.D., M.E. Bauer, and C.S.T. Daughtry. 1986. Effects of nitrogen fertilization on growth and reflectance characteristics of winter wheat. Remote Sens. Environ. 19:47-61.

Kleman, J. and E. Fagerlund. 1987. Influence of different nitrogen and irrigation treatments on the spectral reflectance of barley. Remote Sens. Environ. 21:1-14.

Large, E.C. 1954. Growth stages in cereals. Plant Pathol. 3:128-129. 
Marten, G.C. 1985. Alfalfa hay seen in new light. Agricultural Research September. p. 6-9.

Moll, R.H., E.J., Kamprath, and W.A. Jackson. 1982. Analysis and interpretation of factors which contribute to efficiency of nitrogen utilization. Agron $\mathrm{J}$. $74: 562-564$.

Morra, M.J., M.H. Hall, and L.L. Freeborn. 1991. Carbon and nitrogen analysis of soil fractions using near-infrared reflectance spectroscopy. Soil Sci. Soc. Am. J. 55:288-291.

Mulla, D.J., A.U. Bhatti, M.W. Hammond, and J. A. Benson. 1992. A comparison of winter wheat yield and quality under uniform versus spatially variable fertilizer management. Agric. Ecosystems Environ. 38:301-311.

Penney, D.C., S.C. Nolan, R.C. McKenzie, T.W. Goddard, and L. Kryzanowski. 1996. Yield and nutrient mapping for site specific fertilizer management. Commun. Soil Sci. Plant Anal. 27(5-8):1265-1279.

Raun, W.R., J.B. Solie, G.V. Johnson, M.L. Stone, R.W. Whitney, H.L. Lees, H. Sembiring, and S.B. Phillips. 1998. Micro-variability in soil test, plant nutrient and yield parameters. Soil Sci. Soc. Am. J. 62:683-690.

Roth, G.W., R.H. Fox, and H.G. Marshall. 1989. Plant tissue tests for predicting nitrogen fertilizer requirements of winter wheat. Agron. J. 81:502-507.

SAS Institute Inc. 1988. SAS/STAT User's Guide. 6.03 ed. SAS Institute Inc., Cary, NC. 
Sawyer, J.E. 1994. Concepts of variable rate technology with considerations for fertilizer application. J. Prod. Agric. 7:195-201.

Schepers, J.S., D.D. Francis, and M.T. Thompson. 1989. Simultaneous determination of total $\mathrm{C}$, total $\mathrm{N}$, and ${ }^{15} \mathrm{~N}$ on soil and plant material. Commun. in Soil Sci. Plant Anal. 20(9\&10):949-959.

Solie, J.B., W.R. Raun, R.W. Whitney, M.L. Stone, J.D. Ringer. 1996. Optical sensor based field element size and sensing strategy for nitrogen application. Trans. ASAE 39(6):1983-1992.

Stone, M.L., J.B. Solie, R.W. Whitney, W.R. Raun, and H.L. Lees. 1996a. Sensors for detection of nitrogen in winter wheat. SAE Technical paper series. SAE Paper No. 961757. SAE, Warrendale PA.

Stone, M.L., J.B. Solie, W.R. Raun, R.W. Whitney, S.L. Taylor, and J.D. Ringer. 1996b. Use of spectral radiance for correcting in-season fertilizer nitrogen deficiencies in winter wheat. Trans. ASAE 39(5):1623-1631.

Thomas, J.R. and H.W. Gausman. 1977. Leaf reflectance vs. leaf chlorophyll and carotenoid concentrations for eight crops. Agron. J. 69:799-802.

Thomas, J.R. and G.F. Oerther. 1972. Estimating nitrogen content of sweet pepper leaves by reflectance measurements. Agron. J. 64:11-13.

Vansichen, R. and J. de Baerdemaeker. 1993. A measurement technique for yield mapping of corn silage. J. Agric. Engr. Res. 55:1-10.

Walburg, G., M.E. Bauer, C.S.T. Daughtry, and T.L. Housley. 1982. Effects of nitrogen nutrition on the growth, yield, and reflectance characteristics of corn canopies. Agron J. 74:677-683. 
Wibawa, W.D., D.L. Dludlu, L.J. Swenson, D.G. Hopkins, and W.C. Dahnke. 1993. Variable fertilizer application based on yield goal, soil fertility, and soil map unit. J. Prod. Agric. 6:255-261.

Wood, C.W., D.W. Reeves, R.R. Duffield, and K.L. Edmisten. 1992. Field chlorophyll measurements for evaluation of corn nitrogen status. J. Plant Nutr. 15:487-500. 
Table 1. Initial surface $(0-15 \mathrm{~cm})$ soil test characteristics and soil classification at Hennessey, Perkins, and Tipton, Oklahoma.

\begin{tabular}{|c|c|c|c|c|c|c|c|}
\hline Location & $\mathrm{pH}$ & $P$ & $\mathrm{~K}$ & $\begin{array}{l}\mathrm{NH}_{4}-\mathrm{N} \\
-\mathrm{mg} \mathrm{kq}^{-1}\end{array}$ & $\mathrm{NO}_{3}-\mathrm{N}$ & Total N & Organic C \\
\hline Hennessey & 6.5 & 144 & 457 & 5 & 14 & 1.09 & 12.37 \\
\hline Classification & \multicolumn{7}{|c|}{ Shellabarger sandy loam (fine-loamy, mixed, thermic Udic Argiustoll) } \\
\hline Perkins & 6.7 & 51 & 143 & 5 & 4 & 0.60 & 5.33 \\
\hline Classification & \multicolumn{7}{|c|}{ Teller sandy loam (fine, mixed, thermic Udic Argiustoll) } \\
\hline Tipton, 1996 & 7.3 & 44 & 523 & 4 & 9 & 0.69 & 7.53 \\
\hline Tipton, 1997 & 7.5 & 40 & 359 & 11 & 10 & 0.69 & 7.53 \\
\hline Classification & \multicolumn{7}{|c|}{ Tillman-Hollister clay loam (fine, mixed, thermic Pachic Argiustoll) } \\
\hline
\end{tabular}


Table 2. Treatment structure for resolution study.

\begin{tabular}{crr}
\hline reatment & $\begin{array}{c}\text { Treatment } \\
\text { Resolution }\end{array}$ & No. of Subplots \\
\hline 1 & $0.84 \mathrm{~m}^{2}$ & 64 \\
2 & $3.34 \mathrm{~m}^{2}$ & 16 \\
3 & $13.38 \mathrm{~m}^{2}$ & 4 \\
4 & $53.51 \mathrm{~m}^{2}$ & 1 \\
\hline
\end{tabular}


Table 3. Linear regression models determined for a linear $\mathrm{NDVI}-\mathrm{N}$ rate scale.

\begin{tabular}{lccc}
\hline \multicolumn{1}{c}{ Location } & Minimum NDVI & Maximum NDVI & Equation $^{*}$ \\
\hline Hennessey & 0.70 & 0.81 & $y=-916.20 x+740.07$ \\
Tipton, 1996-97 & 0.18 & 0.48 & $y=-325.59 x+157.34$ \\
Perkins & 0.28 & 0.63 & $y=-290.88 x+182.88$ \\
\hline * $x=$ NDV; $y=$ N rate & & &
\end{tabular}


Table 4. Analysis of variance for NDVI, nitrogen rate, grain yield, nitrogen uptake, and efficiency of use in wheat at Hennessey, OK, 1996-97.

\begin{tabular}{|c|c|c|c|c|c|c|}
\hline $\begin{array}{l}\text { Source of } \\
\text { variation }\end{array}$ & $\mathrm{df}$ & NDVI & $\begin{array}{c}\text { Nitrogen } \\
\text { rate } \\
\mathrm{kg} \mathrm{ha}^{-1}\end{array}$ & $\begin{array}{c}\text { Grain } \\
\text { yield } \\
\mathrm{kg} \mathrm{ha}^{-1}\end{array}$ & $\begin{array}{l}\text { Nitrogen } \\
\text { uptake } \\
\mathrm{kg} \mathrm{ha}^{-1}\end{array}$ & $\begin{array}{c}\text { Efficiency } \\
\text { of use }\end{array}$ \\
\hline Replication & 2 & ns & ns & ean Squa & ns & ns \\
\hline Resolution & 3 & ns & ns & ns & ns & $\mathrm{ns}$ \\
\hline Error & 6 & 0.0001 & 68.33 & 188670 & 145.59 & 788.79 \\
\hline \multicolumn{7}{|l|}{ Resolution, $\mathrm{m}^{2}$} \\
\hline 0.84 & & 0.78 & 32.36 & 2039 & 55.84 & 64.17 \\
\hline 3.34 & & 0.77 & 39.06 & 1842 & 64.06 & 47.92 \\
\hline 13.38 & & 0.79 & 21.32 & 1948 & 77.60 & 95.50 \\
\hline 53.51 & & 0.78 & 29.74 & 2574 & 58.74 & 99.45 \\
\hline SED & & 0.01 & 6.75 & 355 & 9.85 & 22.93 \\
\hline CV, \% & & 1 & 27 & 21 & 19 & 37 \\
\hline
\end{tabular}


Table 5. Analysis of variance for NDVI, nitrogen rate, grain yield, nitrogen uptake, and efficiency of use in wheat at Tipton, OK, 1996-97.

\begin{tabular}{|c|c|c|c|c|c|c|}
\hline $\begin{array}{l}\text { Source of } \\
\text { variation }\end{array}$ & $d f$ & NDVI & $\begin{array}{c}\text { Nitrogen } \\
\text { rate } \\
\mathrm{kg} \mathrm{ha}^{-1}\end{array}$ & $\begin{array}{c}\text { Grain } \\
\text { yield } \\
\mathrm{kg} \mathrm{ha}^{-1}\end{array}$ & $\begin{array}{c}\text { Nitrogen } \\
\text { uptake } \\
\mathrm{kg} \mathrm{ha}^{-1}\end{array}$ & $\begin{array}{c}\text { Efficiency } \\
\text { of use }\end{array}$ \\
\hline Replication & 2 & ns & $\mathrm{ns}$ & $\begin{array}{c}\text { ean Sque } \\
\text { ns }\end{array}$ & ns & ns \\
\hline Resolution & 3 & ns & ns & ns & ns & ns \\
\hline Error & 6 & 0.0031 & 395.11 & 52414 & 26.90 & 21.59 \\
\hline \multicolumn{7}{|l|}{ Resolution, $\mathrm{m}^{2}$} \\
\hline 0.84 & & 0.33 & 54.44 & 582 & 17.74 & 10.93 \\
\hline 3.34 & & 0.30 & 66.44 & 656 & 13.67 & 9.48 \\
\hline 13.38 & & 0.38 & 37.45 & 572 & 16.07 & 19.23 \\
\hline 53.51 & & 0.34 & 53.48 & 645 & 19.91 & 12.52 \\
\hline SED & & 0.05 & 16.23 & 187 & 4.23 & 14.39 \\
\hline CV,$\%$ & & 16 & 38 & 37 & 31 & 36 \\
\hline
\end{tabular}


Table 6. Analysis of variance for NDVI, nitrogen rate, grain yield, nitrogen uptake, and efficiency of use in wheat at Perkins, OK, 1997-98.

\begin{tabular}{|c|c|c|c|c|c|c|}
\hline $\begin{array}{l}\text { Source of } \\
\text { variation }\end{array}$ & df & NDVI & $\begin{array}{c}\text { Nitrogen } \\
\text { rate } \\
\mathrm{kg} \mathrm{ha}^{-1}\end{array}$ & $\begin{array}{c}\text { Grain } \\
\text { yield } \\
\mathrm{kg} \mathrm{ha}^{-1}\end{array}$ & $\begin{array}{c}\text { Nitrogen } \\
\text { uptake } \\
\mathrm{kg} \mathrm{ha}^{-1}\end{array}$ & $\begin{array}{c}\text { Efficiency } \\
\text { of use }\end{array}$ \\
\hline Replication & 2 & * & ns & ean Squa & ns & $*$ \\
\hline Resolution & 3 & ns & ns & ns & ns & ns \\
\hline Error & 6 & 0.0009 & 292.84 & 24114 & 15.51 & 79.46 \\
\hline \multicolumn{7}{|l|}{ Resolution, $\mathrm{m}^{2}$} \\
\hline 0.84 & & 0.45 & 56.95 & 2323 & 51.53 & 44.25 \\
\hline 3.34 & & 0.40 & 74.17 & 2329 & 52.30 & 33.47 \\
\hline 13.38 & & 0.42 & 69.28 & 2473 & 54.21 & 38.77 \\
\hline 53.51 & & 0.42 & 73.93 & 2555 & 60.27 & 37.58 \\
\hline SED & & 0.02 & 13.97 & 127 & 3.22 & 7.28 \\
\hline$C V, \%$ & & 7 & 25 & 6 & 7 & 23 \\
\hline
\end{tabular}


Table 7. Coefficients of variation, by treatment, for grain yield and efficiency of use in wheat at Perkins, OK, 1997-98.

\begin{tabular}{lcc}
\hline Resolution, $\mathrm{m}^{2}$ & $\begin{array}{c}\text { Grain Yield } \\
\text { - }\end{array}$ & $\begin{array}{c}\text { Efficiency of Use } \\
\text {----Coefficient of Variation, \%------ }\end{array}$ \\
\hline 0.84 & 7 & 35 \\
3.34 & 16 & 37 \\
13.38 & 9 & 36 \\
53.51 & 10 & 37 \\
\hline
\end{tabular}


Table 8. Analysis of variance for NDVI, nitrogen rate, grain yield, nitrogen uptake, and efficiency of use in wheat at Tipton, OK, 1997-98.

\begin{tabular}{|c|c|c|c|c|c|c|}
\hline $\begin{array}{l}\text { Source of } \\
\text { variation }\end{array}$ & $\mathrm{df}$ & NDVI & $\begin{array}{c}\text { Nitrogen } \\
\text { rate } \\
\mathrm{kg} \mathrm{ha}^{-1}\end{array}$ & $\begin{array}{c}\text { Grain } \\
\text { yield } \\
\mathrm{kg} \mathrm{ha}^{-1}\end{array}$ & $\begin{array}{c}\text { Nitrogen } \\
\text { uptake } \\
\mathrm{kg} \mathrm{ha}^{-1}\end{array}$ & $\begin{array}{l}\text { Efficiency } \\
\text { of use }\end{array}$ \\
\hline Replication & 2 & ns & * & $\begin{array}{c}\text { ean Squa } \\
\text { ns }\end{array}$ & ns & ns \\
\hline Resolution & 3 & ns & ns & * & ns & ns \\
\hline Error & 6 & 0.00535 & 175.01 & 76678 & 105.90 & 66.05 \\
\hline \multicolumn{7}{|l|}{ Resolution, $\mathrm{m}^{2}$} \\
\hline 0.84 & & 0.57 & 53.78 & 2809 & 49.19 & 56.07 \\
\hline 3.34 & & 0.55 & 70.47 & 3196 & 57.26 & 46.96 \\
\hline 13.38 & & 0.55 & 75.60 & 3354 & 62.60 & 45.34 \\
\hline 53.51 & & 0.56 & 73.93 & 3706 & 74.21 & 54.45 \\
\hline SED & & 0.06 & 10.80 & 226 & 8.40 & 6.64 \\
\hline $\mathrm{CV}, \%$ & & 13 & 19 & 8 & 17 & 16 \\
\hline
\end{tabular}


Table 9. Coefficients of variation, by treatment, for grain yield and efficiency of use in wheat at Tipton, OK, 1997-98.

\begin{tabular}{lcc}
\hline Resolution, $\mathrm{m}^{2}$ & \multicolumn{2}{c}{ Coefficient of Variation (CV), \% } \\
\cline { 2 - 3 } & Grain Yield & Efficiency of Use \\
\hline 0.84 & 15 & 27 \\
3.34 & 14 & 16 \\
13.38 & 5 & 15 \\
53.51 & 8 & 36 \\
\hline
\end{tabular}


Figure 1. Diagram of the physical layout of the experiments showing treatments $(1-4)$ and resolution within treatment.

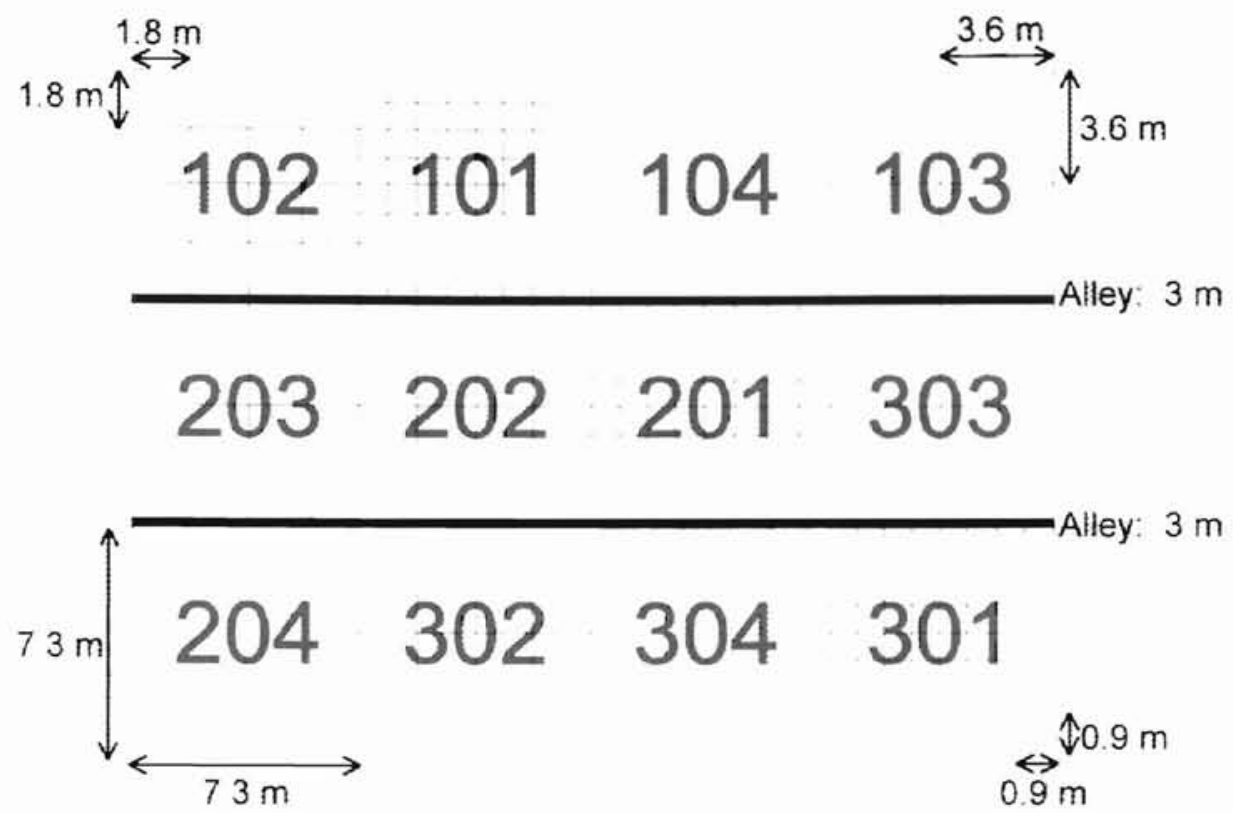


APPENDIX 
Table 10. Minimum and maximum NDVI values and $\mathrm{N}$ rates by location and year.

\begin{tabular}{|ll|}
\hline Hennessey, 1996-97 \\
\hline NDVI & N Rate \\
Min 0.70 & $112 \mathrm{~kg} \mathrm{ha}^{-1}$ \\
Max 0.81 & $0 \mathrm{~kg} \mathrm{ha}^{-1}$ \\
\hline
\end{tabular}

\begin{tabular}{|ll|}
\hline Tipton, 1996-97 \\
\hline NDVI & N Rate \\
Min 0.18 & $112 \mathrm{~kg} \mathrm{ha}^{-1}$ \\
Max 0.48 & $0 \mathrm{~kg} \mathrm{ha}^{-1}$ \\
\hline
\end{tabular}

\begin{tabular}{|ll|}
\hline Perkins, 1997-98 & \\
\hline NDVI & N Rate \\
Min 0.28 & $112 \mathrm{~kg} \mathrm{ha}^{-1}$ \\
Max 0.63 & $0 \mathrm{~kg} \mathrm{ha}^{-1}$ \\
\hline
\end{tabular}

\begin{tabular}{|ll|}
\hline Tipton, 1997-98 & \\
\hline NDVI & N Rate \\
Min 0.28 & $0 \mathrm{~kg} \mathrm{ha}^{-1}$ \\
Mid 0.46 & $112 \mathrm{~kg} \mathrm{ha}^{-1}$ \\
Max 0.74 & $11.2 \mathrm{~kg} \mathrm{ha}^{-1}$ \\
\hline
\end{tabular}


Figure 2. Contour map of NDVI values at Hennessey, OK, 1996-97.

Field Length: $27.97 \mathrm{~m}$

Field Width: $29.18 \mathrm{~m}$

Plot Size: $\quad 53.51 \mathrm{~m}^{2}$

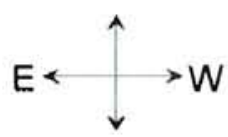

Treatment \# of Subplots Treated

\begin{tabular}{rrr} 
& & Resolution \\
\hline 1 & 64 & $0.84 \mathrm{~m}^{2}$ \\
2 & 16 & $3.34 \mathrm{~m}^{2}$ \\
3 & 4 & $13.38 \mathrm{~m}^{2}$ \\
4 & 1 & $53.51 \mathrm{~m}^{2}$
\end{tabular}

N

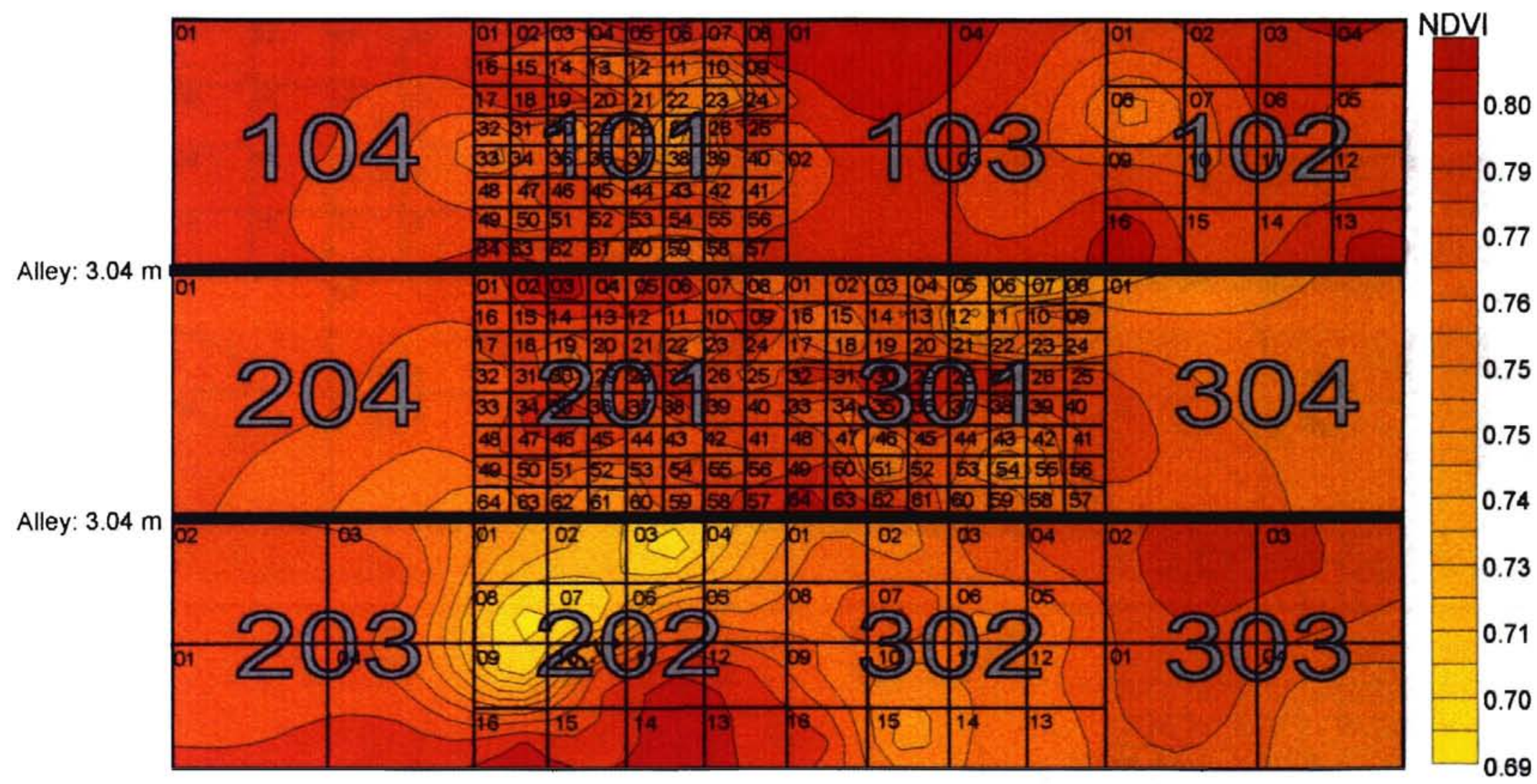

Alley: $3.04 \mathrm{~m}$

Alley: $3.04 \mathrm{~m}$ 
Figure 3. Contour map of NDVI values at Tipton, OK, 1996-97.

Field Length: $27.97 \mathrm{~m}$

Field Width: $29.18 \mathrm{~m}$

Plot Size:

$53.51 \mathrm{~m}^{2}$

\begin{tabular}{rrrr}
$\mathrm{N} \longleftarrow$ & Treatment & \# of Subplots & $\begin{array}{c}\text { Treated } \\
\text { Resolution }\end{array}$ \\
\cline { 2 - 4 } & 1 & 64 & $0.84 \mathrm{~m}^{2}$ \\
2 & 16 & $3.34 \mathrm{~m}^{2}$ \\
3 & 4 & $13.38 \mathrm{~m}^{2}$ \\
4 & 1 & $53.51 \mathrm{~m}^{2}$
\end{tabular}

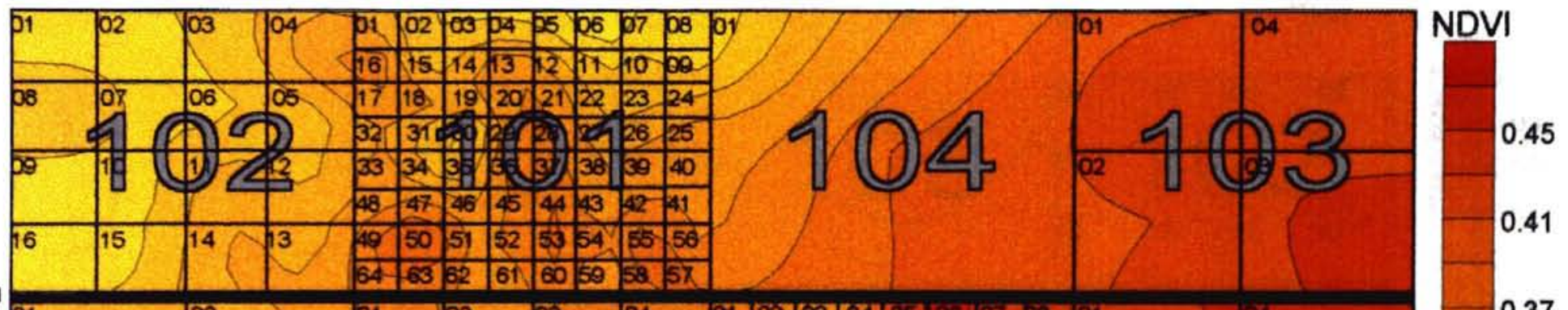

Alley: $3.04 \mathrm{~m}$

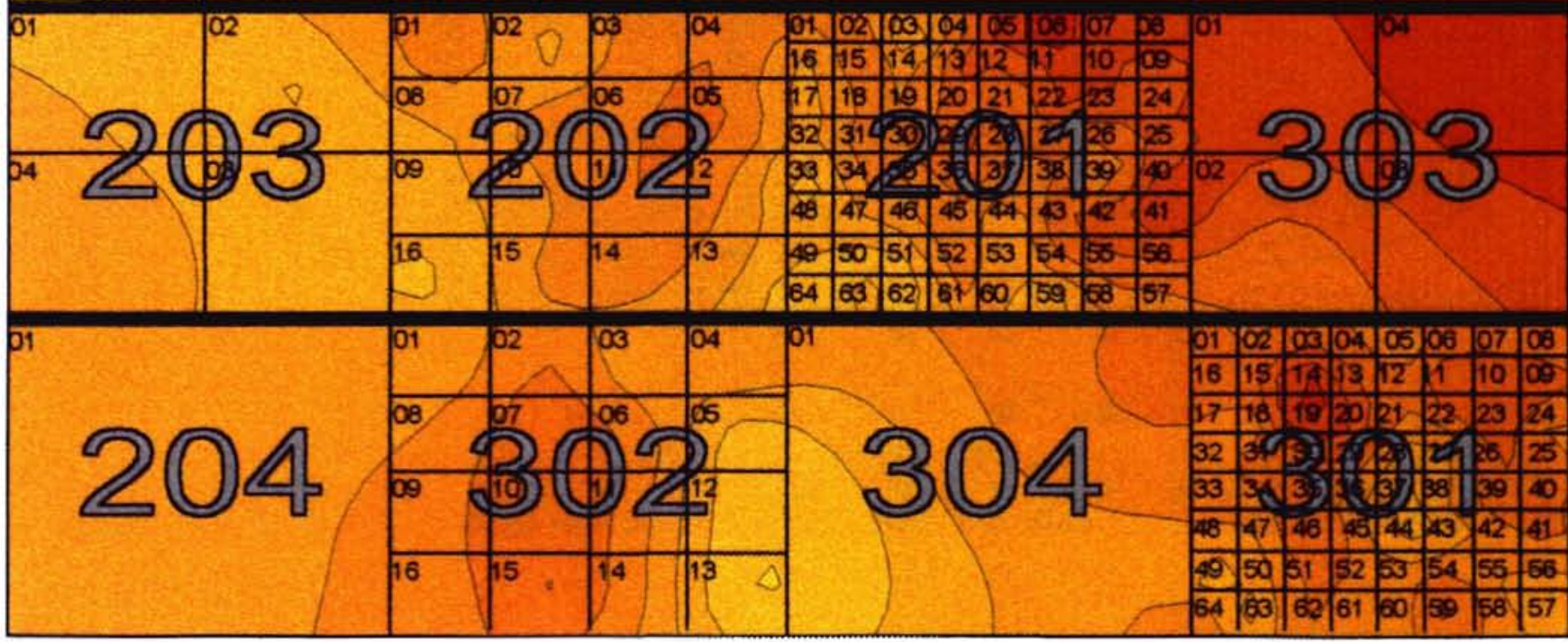


Figure 4. Contour map of NDVI values at Perkins, OK, 1997-98.

Field Length: $27.97 \mathrm{~m}$ Field Width: $29.18 \mathrm{~m}$

Plot Size: $\quad 53.51 \mathrm{~m}^{2}$

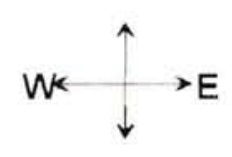

\begin{tabular}{ccr} 
Treatment & \# of Subplots & $\begin{array}{c}\text { Treated } \\
\text { Resolution }\end{array}$ \\
\hline 1 & 64 & $0.84 \mathrm{~m}^{2}$ \\
2 & 16 & $3.34 \mathrm{~m}^{2}$ \\
3 & 4 & $13.38 \mathrm{~m}^{2}$ \\
4 & 1 & $53.51 \mathrm{~m}^{2}$
\end{tabular}
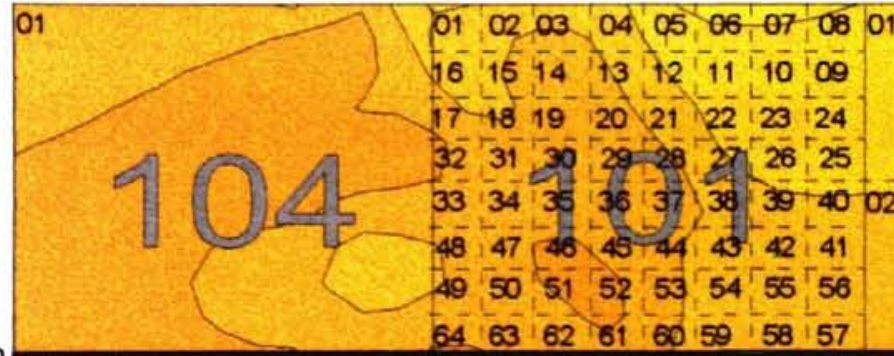

04

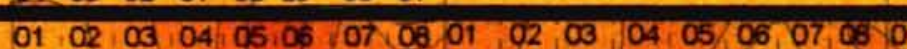

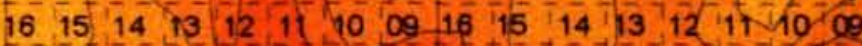

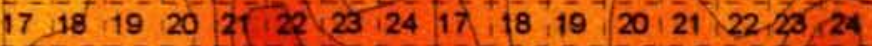

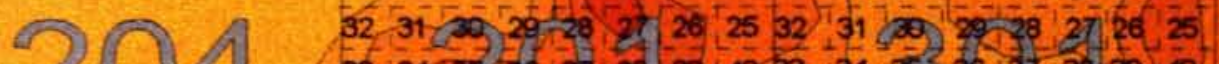

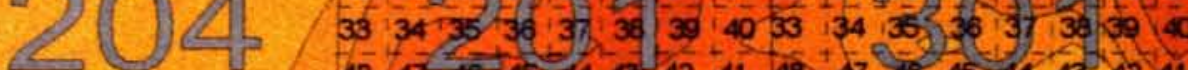

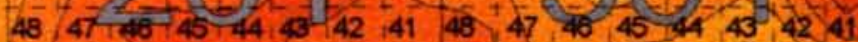

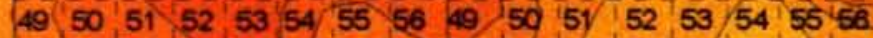

Alley: $3.04 \mathrm{~m}$

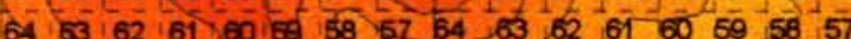
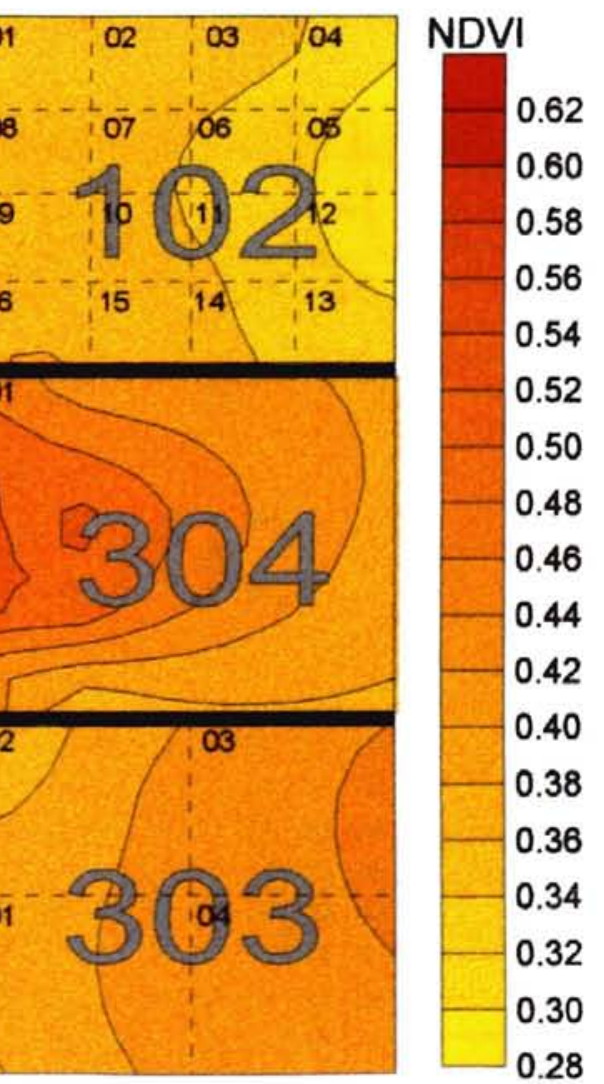
Figure 5. Contour map of NDVI values at Tipton, OK, 1997-98.

Field Length: $27.97 \mathrm{~m}$

Field Width: $29.18 \mathrm{~m}$

Plot Size:

$53.51 \mathrm{~m}^{2}$

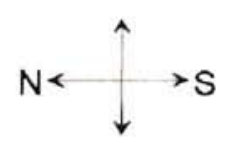

\begin{tabular}{ccr} 
Treatment & \# of Subplots & $\begin{array}{c}\text { Treated } \\
\text { Resolution }\end{array}$ \\
\hline 1 & 64 & $0.84 \mathrm{~m}^{2}$ \\
2 & 16 & $3.34 \mathrm{~m}^{2}$ \\
3 & 4 & $13.38 \mathrm{~m}^{2}$ \\
4 & 1 & $53.51 \mathrm{~m}^{2}$
\end{tabular}

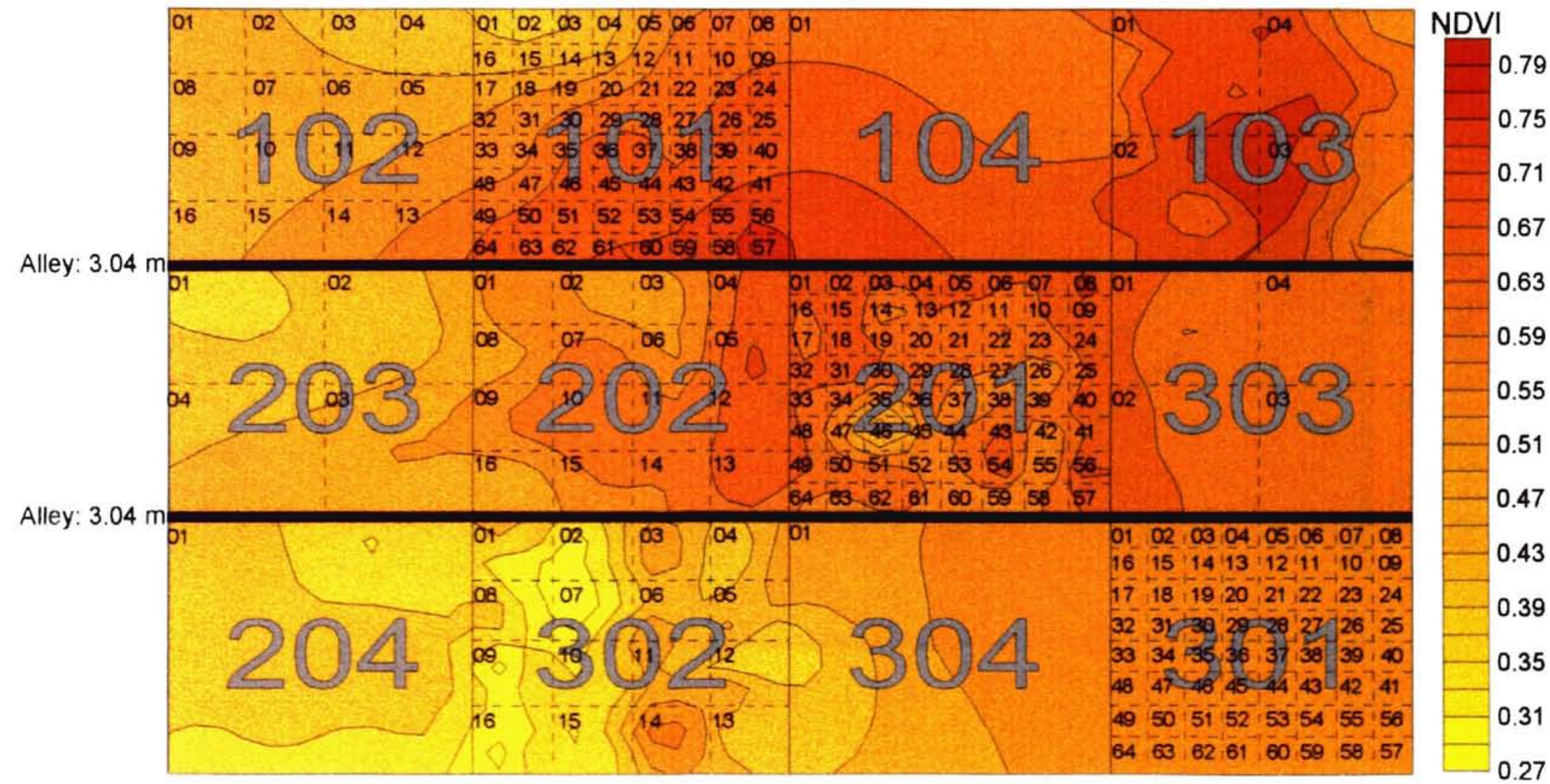


Figure 6. Relationship between NDVI, $\mathrm{N}$ uptake, and $\mathrm{N}$ rate

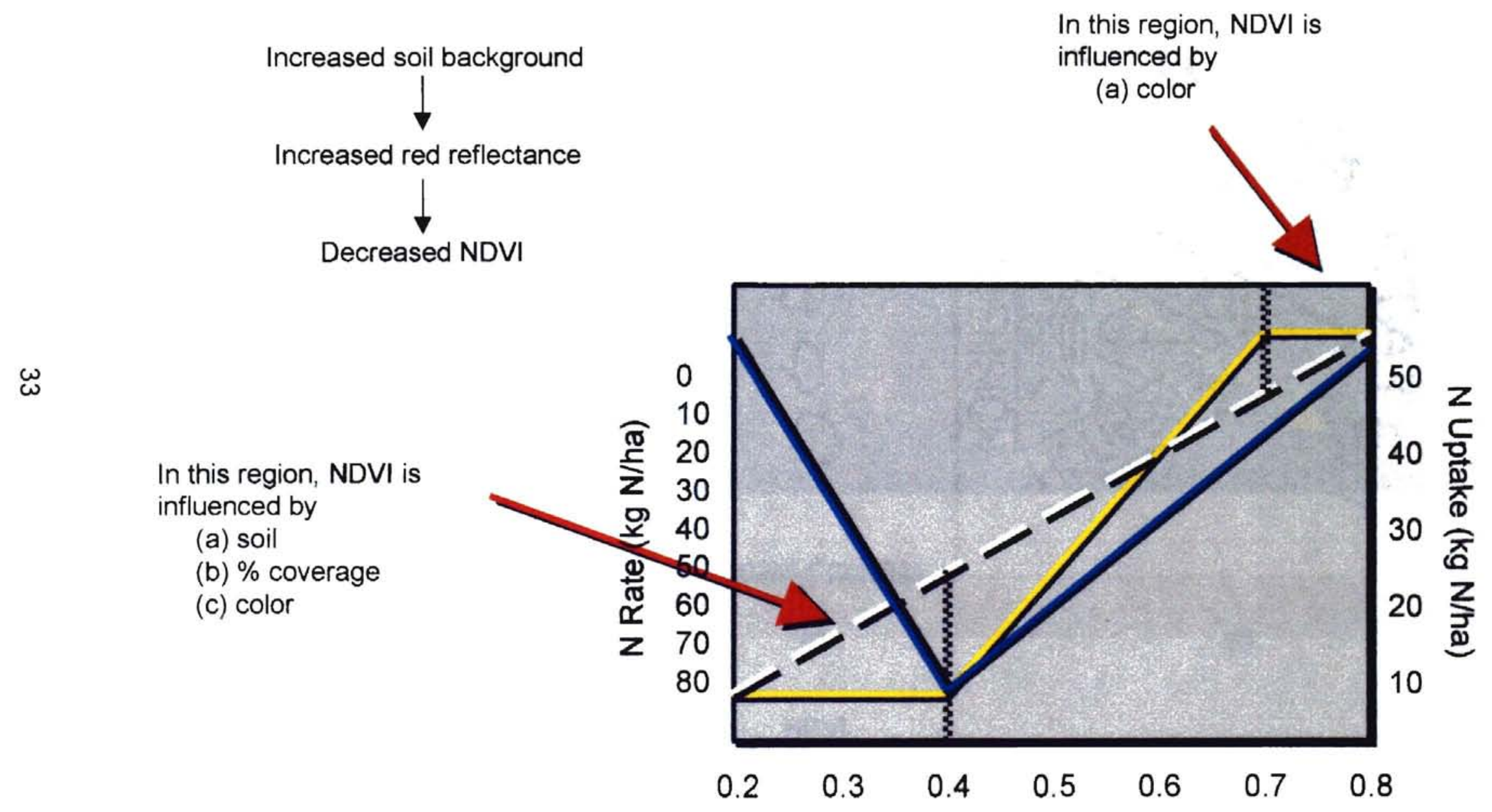


Figure 7. Tipton, January 15,1998 , Feekes 5

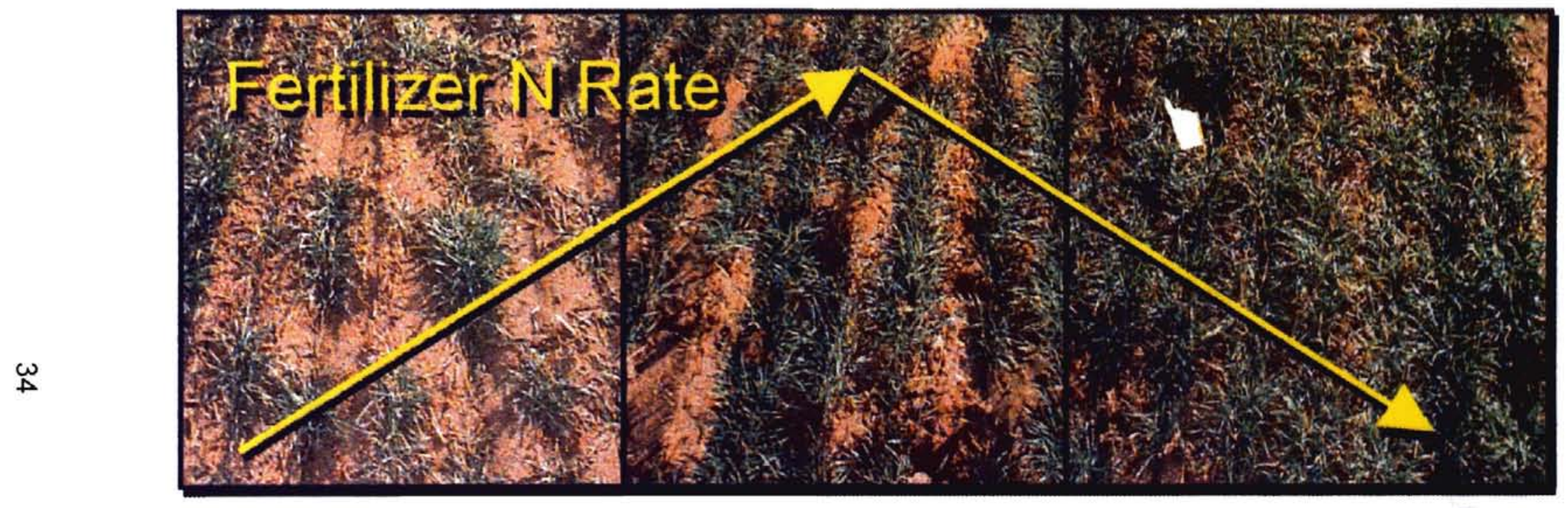

\section{Percent Coverage}

NDVI 


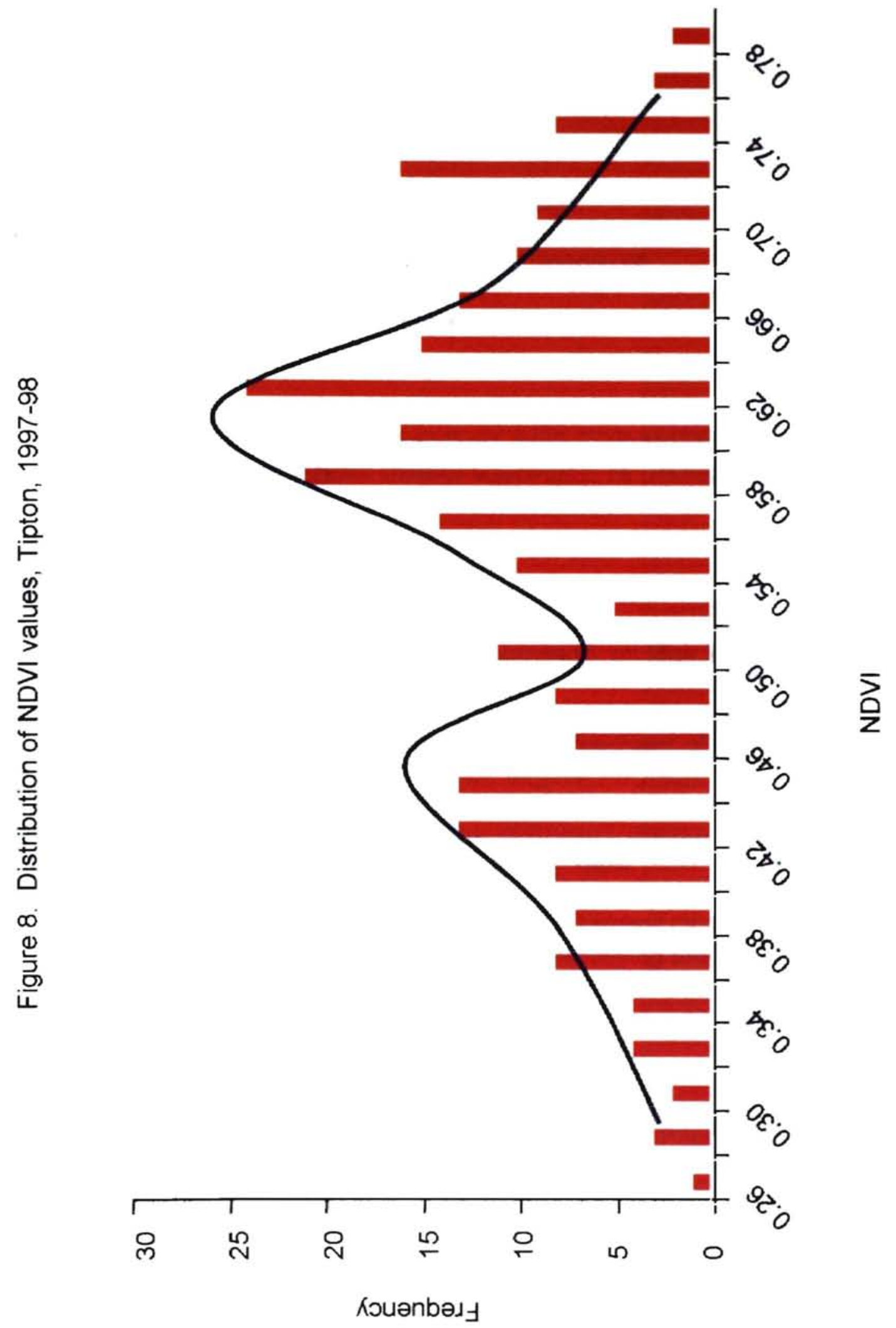




\author{
VITA \\ Joanne LaRuffa \\ Candidate for the Degree of \\ Master of Science
}

Thesis: OPTIMUM FIELD ELEMENT SIZE FOR MAXIMUM YIELDS IN WINTER WHEAT USING VARIABLE NITROGEN RATES

Major Field: Agronomy

Biographical:

Personal Data: Born in Rockville, Maryland, on May 20, 1974.

Education: Graduated from The Academy of the Holy Cross, Kensington, Maryland, in May 1992. Received Bachelor of Science degree in Environmental Science from Virginia Polytechnic Institute and State University, Blacksburg, Virginia, in May 1996. Completed the requirements for the Master of Science degree in Soil Science at Oklahoma State University in May 1999.

Professional Experiences: Employed by National Oceanic and Atmospheric Administration as a surveying technician from May 1996 to October 1996; employed by Oklahoma State University, Department of Plant and Soil Sciences as a graduate research assistant, January 1997 to present.

Professional Memberships: American Society of Agronomy, Soil Science Society of America, Gamma Sigma Delta, Phi Kappa Phi, Sigma Xi. 